Volume I, No 1, Februari 2017

Hal 047-067

\title{
IDENTIFIKASI BAHAYA PADA AKTIVITAS PATROLI LAUT OLEH PENGAWAS PERIKANAN DI JAKARTA
}

\author{
Identification of Hazard in Marine Patrol Activity by Fisheries Inspector in Jakarta \\ Oleh: \\ Singgih Prihadi Aji ${ }^{*}$, Budhi Hascaryo Iskandar ${ }^{2}$, Fis Purwangka² \\ ${ }^{1}$ Pengawas Sumber Daya Kelautan dan Perikanan \\ ${ }^{2}$ Departemen PSP FPIK IPB \\ *Korespondensi: singgih.pa@gmail.com
}

\begin{abstract}
ABSTRAK
FAO (2010) menyebutkan bahwa penangkapan ikan merupakan salah satu pekerjaan yang paling berbahaya di dunia. Pengawasan terhadap penangkapan ikan di laut merupakan bagian dari pengelolaan perikanan yang juga merupakan satu pekerjaan yang memiliki potensi bahaya tinggi. Jumlah kecelakaan yang dihimpun oleh Badan Nasional Penanggulangan Bencana (BNPB) Indonesia antara tahun 2011-2014, terjadi 80 kejadian yang terdiri dari kecelakaan di darat, laut dan udara. Dari 80 kejadian kecelakaan, sebanyak 55 kejadian merupakan kecelakaan di laut yang melibatkan kapalkapal dari berbagai jenis, meliputi kapal niaga, kapal kargo, kapal/perahu nelayan, kapal patroli milik pemerintah dan kapal lainnya. Penting untuk mempelajari keselamatan awak kapal untuk mengetahui bahaya dan risiko dalam patroli pengawasan SDKP di laut. Tujuan penelitian ini adalah menginventaris, mengidentifikasi dan mendeskripsikan semua kondisi atau peluang konsekuensi keselamatan kerja Pengawas Perikanan yang disebabkan oleh kesalahan manusia pada patroli pengawasan SDKP di laut menggunakan speedboat pengawasan. Metode penelitian ini adalah deskriptif numeric. Analisis yang digunakan dalam penelitian ini yaitu dengan metode Formal Safety Assessment. Metode tersebut dilakukan identifikasi aktifitas dengan Hierarchical Task Analysis (HTA). Hasil penelitian menunjukkan bahwa aktivitas yang teridentifikasi pada patroli pengawasan SDKP di laut yang dilakukan oleh pengawas perikanan di Pangkalan PSDKP Jakarta yaitu 84 aktivitas. Aktivitas utama yang teridentifikasi adalah 5 tahap, yaitu persiapan, loading, pelayaran dan pengawasan di laut, penghentian, pemeriksaan dan penahanan kapal perikanan dan kembali ke pangkalan (homebase). Pada aktivitas patroli pengawasan SDKP di laut teridentifikasi masing-masing konsekuensi kegagalan dari aktivitas yaitu kelelahan $25 \%$, luka ringan $14,29 \%$, cedera ringan $7,14 \%$, cedera berat $38,10 \%$, dan fatal $15.48 \%$. Secara umum, penyebab terjadinya kegagalan pada setiap aktifitas dipengaruhi oleh beberapa hal, antara lain adanya dorongan untuk menggunakan prosedur yang berbahaya, lingkungan yang buruk atau tidak mendukung dan adanya bahaya dari keterbatasan kemampuan fisik.
\end{abstract}

Kata kunci: HTA, keselamatan kerja, patroli laut, pengawas perikanan

\begin{abstract}
FAO (2010) mentioned that fishing is one of the most dangerous jobs in the world. Surveillance of fishing is part of the management of fisheries is also the one job that has the potential of high danger. The number of accident was compiled by the national disaster mitigation Agency (BNPB) of Indonesia between the years 2011-2014, occurs 80 events consisting of accidents on land, sea and air. Than 80 incidents accidents, as many as 55 events is an accident at sea involving ships of various types, including commercial ships, cargo ships, boat/fishing vessel, a Government owned patrol boats and other vessels. It is important to study the safety of the ship's crew to know tha hazards and risk in the surveillance patrol SDKP at sea. The purpose of this research is identify, inventory and describe all the condition of
\end{abstract}


opportunities fisheries supervisor safety conseqeunces that are caused by human error on surveillance patrol SDKP at sea using speedboats supervision. The method of this research is a descriptive numeric. The analysis used in the study is the Formal Safety Assessment (FSA) and Hierarchical Task Analysis (HTA) to identification of activities. The result showed that activity was identified on a surveillance patrol SDKP at sea conducted by the Fisheries Inspector is 84 activities. The main activities identified are 5 stages, namely preparation, loading, shipping and surveillance at sea, cessation, screening and detention of vessels fishing and return to base. On a surveillance patrol SDKP activity at sea identified each of the consequences of the failure of activity that are 25\% fatigue, minor injuries $14.29 \%$ mild injuries 7,14\%, major injuries $38.10 \%$, and fatal 15\%. In General, the causes of failure at any activity is influenced by little opportunity to exercise mind and body outside the immediate confines of a job, a poor or hostile environment and a danger that finite physical capabilities will be exceeded.

Keywords: HTA, safety, sea patrol, fisheries inspector

\section{PENDAHULUAN}

Pengawasan aktifitas penangkapan ikan terhadap kapal-kapal perikanan yang dilakukan oleh pengawas perikanan dilakukan di pelabuhan-pelabuhan perikanan dan juga di laut. Pengawasan aktifitas penangkapan ikan di laut tersebut dilakukan melalui patroli pengawasan perikanan dilaut. Kegiatan patroli di laut yang dilakukan oleh pengawas perikanan penuh dengan tantangan serta dihadapkan pada risiko dan ketidakpastian. Peluang risiko dan ketidakpastian salah satunya yaitu kecelakaan di laut yang disebabkan oleh banyak faktor. Faktor-faktor kecelakaan disebabkan oleh kesalahan manusia, alam dan teknis (Ditjen Hubla, 2010). FAO (2010) menyebutkan bahwa penangkapan ikan merupakan salah satu pekerjaan yang paling berbahaya di dunia. Pengawasan terhadap kegiatan penangkapan ikan di laut merupakan bagian dari pengelolaan perikanan yang juga satu pekerjaan yang memiliki potensi bahaya tinggi.

Orang-orang yang bekerja dalam penangkapan ikan dihadapkan pada bahaya kecelakaan di laut yang sering mengakibatkan kemalangan dalam kehidupan sosialnya. FAO (2010) memperkirakan 30 juta nelayan bekerja pada 4 juta kapal perikanan di seluruh dunia, yang terdiri dari 1,3 juta kapal ber dek (decked vessel) dan 2,7 juta kapal tidak ber dek (undecked vessel). Sekitar 98\% dari kapal tersebut berukuran dibawah 24 meter, dan mereka tidak dilindungi oleh peraturan dan regulasi internasional. Jumlah kecelakaan fatal secara global diperkirakan oleh International Labour Organization (ILO) pada tahun 1999 sekitar 24.000 kematian per tahun. FAO memperkirakan jumlah kejadian fatal mungkin lebih tinggi, hal ini karena tingkat kematian di beberapa Negara yang menginformasikan data statistik tersebut tidak tersedia.

Jumlah kecelakaan yang dihimpun oleh Badan Nasional Penanggulangan Bencana (BNPB) Indonesia antara tahun 2011-2014 yaitu sebanyak 80 kejadian yang terdiri dari kecelakaan darat, laut dan udara. Dari 80 kejadian kecelakaan, sebanyak 55 kejadian merupakan kecelakaan di laut yang melibatkan kapal-kapal dari berbagai jenis yang meliputi kapal niaga, kapal kargo, kapal/perahu nelayan, kapal patroli/kapal milik pemerintah dan kapal lainnya. Artinya kecelakaan di laut adalah kecelakaan yang paling sering terjadi. Handayani, et al. (2014) menyebutkan penyebab utama kecelakaan laut yang berujung pada hilangnya nyawa manusia ini adalah murni kesalahan manusia (human error). Penyebab lainnya adalah pengabaian yang dilakukan oleh penyelenggara transportasi laut dan instansi-instansi terkait, serta perlengkapan keselamatan transportasi laut yang jauh dari memadai (FAO, 2010). Data jumlah korban dalam kecelakaan di laut antara tahun 2011-2014 dengan total jumlah korban berjumlah 1396 orang dengan rincian seperti terlihat pada Gambar 1.

Berdasarkan permasalahan tersebut maka perlu dilakukan penelitian terhadap 

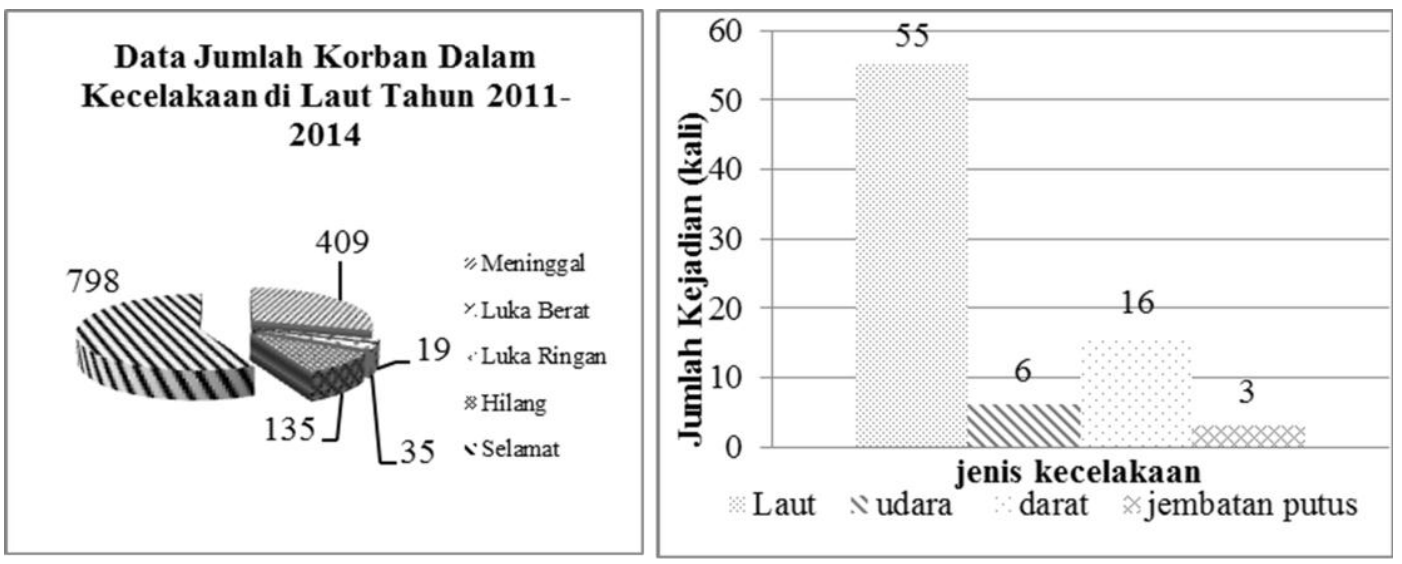

Sumber : data sekunder laporan kecelakaan di laut Badan Nasional Penanggulangan Bencana (BNPB) tahun 2011-2014

Gambar 1 Kecelakaan transportasi 2011 - 2014 di Indonesia

keselamatan kerja Pengawas Perikanan dalam aktivitas patroli laut pengawasan sumber daya kelautan dan perikanan di Pangkalan PSDKP Jakarta termasuk menganalisa prosedur, teknik dan penggunaan teknologi yang tidak membahayakan keselamatan Pengawas Perikanan di atas speedboat pengawasan. Tujuan penelitian ini adalah menginventaris, meng-identifikasi dan mendeskripsikan semua kondisi atau peluang konsekuensi keselamatan kerja Pengawas Perikanan yang disebabkan oleh kesalahan manusia pada partroli pengawasan SDKP di laut menggunakan speedboat pengawasan.

\section{METODE PENELITIAN}

Penelitian dilaksanakan pada bulan Juni s.d Agustus 2016 di Pangkalan Pengawasan Sumber Daya Kelautan dan Perikanan Jakarta dan Patroli pengawasan di Perairan Laut Utara Jawa dengan Pelabuhan Pangkalan (Home Base) di Pelabuhan Perikanan Samudera Nizam Zachman Jakarta. Data yang dihimpun meliputi data primer yang diperoleh dari hasil wawancara 9 orang awak kapal, 14 orang pengawas perikanan dan 4 orang pimpinan unit kerja. Menurut Sugiyono (2011), pengumpulan data primer dapat dilakukan dengan teknik penentuan sampel dengan pertimbangan tertentu (purposive sampling). Hal ini dilakukan dengan pertimbangan terbatasnya jumlah pengawas perikanan dan jumlah awak kapal (speedboat pengawasan) yang mengikuti patroli pengawasan SDKP di laut. Pengumpulan data sekunder meliputi :

1. Data informasi kecelakaan kerja di laut di wilayah kerja Pangkalan PSDKP Jakarta

2. Data rekapitulasi operasional kapal pengawas/speedboat pengawasan

3. Data keragaan sumber daya manusia di Pangkalan PSDKP Jakarta

4. Data laporan pengawasan di Pangkalan PSDKP Jakarta

Data yang diperoleh direkapitulasi dalam bentuk tabel dan gambar, selanjutnya dianalisis secara deskriptif numeric.

\section{Analisis Data}

Analisis yang digunakan dalam penelitian ini yaitu dengan metode Formal Safety Assessment. Metode tersebut dilakukan identifikasi aktifitas dengan Hierarchical Task Analysis (HTA). Dalam HTA juga dikenal plan yang menjelaskan mengenai urutan dan kondisi suatu aktifitas yang dilakukan (Lane et al. 2008). Langkah-langkah yang dilakukan dalam melakukan HTA adalah sebagai berikut:
a) Mengidentifikasi aktifitas utama yang akan di analisis, dengan menentukan tujuan serta batasannya.
b) Memecahkan aktifitas utama menjadi sub aktifitas dan membangun plan
c) Menghentikan sub aktifitas berdasarkan tingkat rinciannya
d) Melanjutkan proses penguraian aktifitas 
e) Mengelompokkan beberapa sub aktifitas (jika terlalu detail) ke level yang lebih tinggi dari sub aktifitas.

\section{HASIL DAN PEMBAHASAN}

Kegiatan patroli pengawasan sumber daya kelautan dan perikanan merupakan bagian dari pengelolaan perikanan di Indonesia yang dilakukan Direktorat Jenderal Pengawasan Sumber Daya Kelautan dan Perikanan dan dioperasikan oleh Unit Pelaksana Teknis (UPT)/Satuan Kerja dan Dinas Kelautan dan Perikanan yag berada di daerah.

Patroli pengawasan dilakukan menggunakan speedboat pengawasan karena $80 \%$ perairan Indonesia merupakan perairan kepulauan yang membutuhkan sarana pengawasan yang handal. Speedboat pengawasan ini memiliki keunggulan pada kecepatan dan stabilitas, dengan kecepatan speedboat pengawasan rata-rata diatas 20 knot mampu melakukan pengejaran terhadap para pelaku pelanggaran di daerah pesisir, sungai, danau maupun waduk (PSDKP, 2013).

Speedboat pengawasan terdiri dari beberapa jenis, yaitu tipe marlin, tipe dolphin, napoleon dan tipe albacore. Speedboat yang digunakan di Pangkalan PSDKP Jakarta yaitu speedboat dengan tipe Dolphin dengan ukuran panjang (LOA) 8 meter, dengan daya mesin $2 \mathrm{x}$ 80-115 HP outboard, jumlah daya tampung penumpang yaitu 8 orang, desain kecepatan maksimum 15-20 knot, endurance 6 jam, dan kualifikasi sea state 3 . Speedboat lainnya yang digunakan oleh Pangkalan PSDKP Jakarta yaitu tipe Napoleon dengan ukuran panjang (LOA) 12 meter, daya mesin 2 × 200-250 HP outboard, jumlah daya tampung penumpang yaitu 12 orang, desain kecepatan maksimum 20-30 knot, endurance 7 jam dan kualifikasi sea state 4 .

\section{Kondisi Umum Pengawas Perikanan}

Menurut Undang-Undang No. 45 Tahun 2009 tentang Perubahan atas Undang-Undang No.31 Tahun 2004 Tentang Perikanan dalam pasal 66 ayat 1 Menyebutkan bahwa pengawasan perikanan di wilayah pengelolaan perikanan Negara Republik Indonesia dilakukan oleh Pengawas Perikanan. Dalam pasal 66A ayat 1, UU Nomor 45 Tahun 2009, pengawas perikanan merupakan pegawai negeri sipil yang bekerja dibidang perikanan yang diangkat oleh menteri atau pejabat yang ditunjuk. Pengawas Perikanan bertugas untuk mengawasi tertib pelaksanaan ketentuan peraturan perundang-undangan dibidang perikanan (Pasal 66 ayat 2, UU Nomor 45 Tahun 2004 dan ditegaskan juga dalam Permen KP Nomor 17/PERMEN-KP/2014 pasal 1). Dalam Pasal 66B UU Nomor 45 Tahun 2009, Pasal 9 Permen KP Nomor 17/PERMEN$\mathrm{KP} / 2014$ menyebutkan lokasi tugas pengawas yaitu sebagai berikut: (1) Wilayah pengelolaan perikanan (WPP) Negara Republik Indonesia, (2) Kapal Perikanan, (3) Pelabuhan Perikanan dan/ata Pelabuhan lainnya yang ditunjuk, (4) Pelabuhan tangkahan, (5) Sentra kegiatan perikanan, (6) Area pembenihan ikan, (7) Area pembudidayaan ikan, dan (8) Unit pengolahan ikan dan/atauKawasan konservasi perairan.

Pengawasan sumber daya kelautan dan perikanan terhadap kapal perikanan dilakukan menggunakan kapal pengawas/speedboat pengawasan. penggunaan speedboat pengawasan mengacu pada standar pengawakan untuk kapal non-konvensi berbendera Indonesia kategori E yakni standar pelaut pemerintah yang dikaitkan dengan fungsi, tugas, kondisi dan dinasnya. Awak kapal yang ada diatas speedboat pengawasan terdiri dari Nakhoda, juru mudi, awak mesin dan kelasi dengan kualifikasi sebagai berikut :

a) Nakhoda : syarat minimal memiliki keahlian dan sertifikat yang setara dengan ahli Nautika tingkat V/AN V;

b) Juru mudi : syarat minimal memiliki keahlian dan sertifikay yang setara dengan ahli nautika tingkat dasar atau ANT D;

c) Awak Mesin : syarat minimal memiliki keahlian dan sertifikat yang setara dengan ahli teknika tingkat dasar atau AT D;

d) Kelasi: mempunyai pengetahuan tentang pengoperasian kapal dan keselamatan di laut. 
Jumlah awak minimum speedboat pengawasan pada patroli pengawasan SDKP menggunakan speedboat tipe napoleon berjumlah 8 orang awak kapal dan 2-4 orang pengawas perikanan termasuk penyidik pegawai negeri sipil (PPNS) perikanan. Sumber daya manusia (SDM) yang terlibat dalam aktivitas patroli pengawasan di Pangkalan PSDKP Jakarta tahun 2016 yaitu sebanyak 24 orang yang terdiri dari pengawas perikanan dan awak kapal. Jumlah SDM tersebut dibagi bergantian sesuai jadwal patroli yang telah direncanakan dalam satu tahun.

Patroli laut pengawasan SDKP di Pangkalan PSDKP Jakarta memiliki komposisi SDM seperti terlihat pada Gambar 2 yang menunjukkan komposisi jabatan (a) dan tingkat pendidikan (b). komposisi jabatan menunjukkan bahwa $62,50 \%$ diisi oleh pengawas perikanan, artinya pengawasan sumber daya kelautan dan perikanan yang dilakukan menggunakan speedboat pengawasan menjadi tugas utama pengawas perikanan dan jabatan lainnya merupakan jabatan pendukung dalam tugas pengawasan sumberdaya kelautan dan perikanan, termasuk nakhoda yang juga seluruhnya merupakan pengawas perikanan (rangkap jabatan). Rangkap jabatan menurut William (1986) merupakan sesuatu yang dapat menimbulkan kesalahan dalam suatu aktivitas.

Menurut IMO (1995), Nakhoda dan perwira jaga di atas kapal harus memiliki pengetahuan dan keterampilan minimal sesuai dengan ukuran kapal dan daerah pelayaran. Menurut Suwardjo, et al. (2010), untuk menguasai keahlian dan keterampilan tersebut
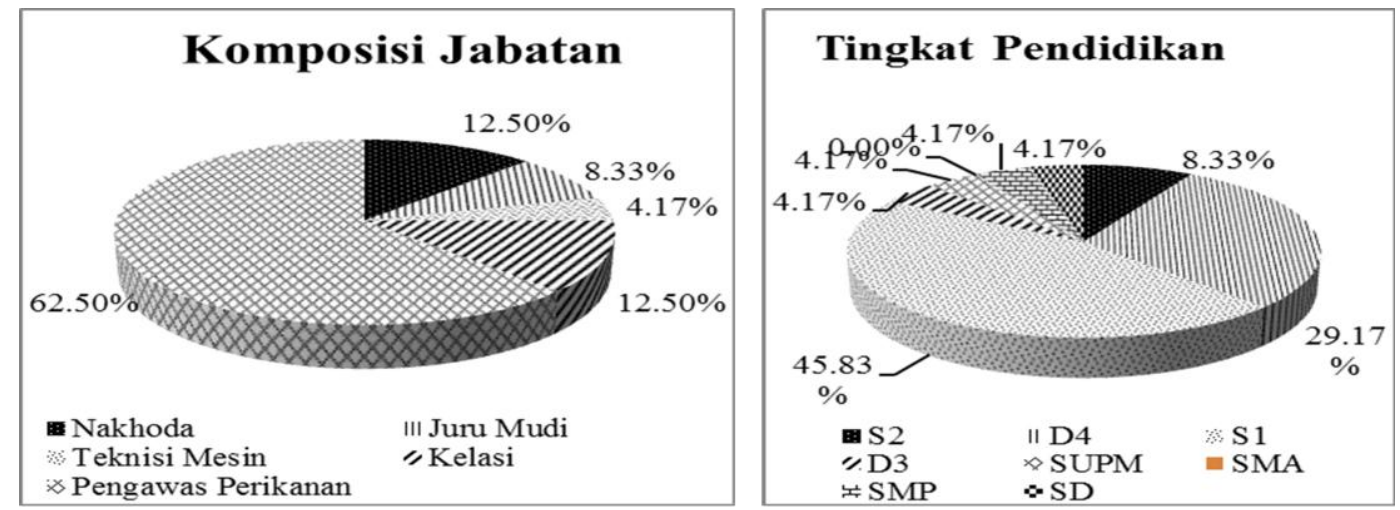

Gambar 2 Kondisi umum SDM pengawasan SDKP di Pangkalan PSDKP Jakarta maka seorang nakhoda kapal minimum berpendidikan menengah perikanan seperti Sekolah Usaha Perikanan Menengah atau pendidikan SLTA umum ditambah pelatihan kepelautan meliputi pelayaran dan pengoperasian kapal, keselamatan dan penangkapan ikan. Nakhoda speedboat pengawasan saat ini yang berjumlah 3 (tiga) orang merupakan lulusan D4 dari Sekolah Tinggi Perikanan yang lulusannya sudah memiliki pengetahuan dan keterampilan mengoperasikan kapal.

Undang-Undang Nomor 17 Tahun 2008 tentang Pelayaran menyebutkan bahwa para perwira pada kapal yang berukuran panjang kurang dari 12 meter harus memiliki sertifikat kepelautan ANKAPIN-III untuk bagian dek dan ANKAPIN-II untuk bagian mesin. Saat ini jabatan teknisi mesin berjumlah 1 (satu) orang dengan pendidikan D4 dari Sekolah Tinggi Perikanan, juru mudi 2 (dua) orang dengan pendidikan D4 dari Sekolah Tinggi Perikanan dan kelasi yang diisi oleh 2 (dua) orang dengan pendidikan SUPM dan SLTP. Tingkat dan jenjang pendidikan yang diraih oleh awak kapal speedboat di Pangkalan PSDKP Jakarta menunjukkan bahwa awak speedboat pengawasan telah sesuai dengan peraturan yang berlaku, sehingga kompetensi untuk menjaga kesamatan kerja dilaut dapat terpenuhi. Kompetensi pekerja terhadap keselamatan kerja seringkali dinilai dari pengetahuan, pengertian serta penerapan peraturan dan prosedur keselamatan kerja, juga dari penerapan atas pelatihan keselamatan kerja yang diperoleh (Davies et al. 2001). 
Komposisi terbesar dari sumber daya manusia yang terlibat dalam aktivitas patroli pengawasan sumber daya kelautan dan perikanan di laut adalah pengawas perikanan yang juga memiliki tingkat pendidikan ratarata yaitu S1 Perikanan, namun tidak seluruh pengawas perikanan mempunyai syarat kompetensi untuk bekerja di atas kapal dalam hal keselamatan di laut. Dengan demikian, walaupun 45,83 \% sudah mengenyam pendidikan tinggi namun belum mendapatkan pelatihan keselamatan diri di laut yang diperoleh melalui Pelatihan Keselamatan Tingkat Dasar (Basic Safety Training, BST) sehingga tercipta kondisi yang kondusif pada saat patroli laut. Andi et al. (2005) menyebutkan bahwa keadaan lingkungan kerja yang kondusif dapat mendukung penerapan program keselamatan kerja dengan optimal bila seluruh pekerja mengutamakan program keselamatan kerja, dan dengan lingkungan kerja yang semakin kondusif diharapkan dapat meningkatkan motivasi pekerja.

Identifikasi kegagalan pada aktivitas patroli laut pengawasan SDKP di Pangkalan PSDKP Jakarta

Aktivitas patroli laut pengawasan SDKP dilakukan menggunakan speedboat pengawasan selama 68 hari dalam satu tahun. Satu trip patroli dilakukan minimal 4-5 hari operasi dengan sistem setiap hari operasi selalu kembali ke homebase untuk istirahat. Patroli dapat dilakukan pada siang atau malam hari, hal ini dapat menimbulkan potensi terjadinya kecelakaan kerja bagi awak kapalnya. Potensi kecelakaan kerja tidak hanya terjadi pada saat berlayar namun dapat terjadi mulai dari persiapan di pangkalan, menuju lokasi pengawasan sampai dengan kembali ke pangkalan. Kecelakaan kerja merupakan kecelakaan yang terjadi dalam lingkungan kerja yang dapat terjadi karena kondisi lingkungan kerja yang tidak aman ataupun karena human error (Restuputri et al. 2015).

Potensi terjadinya kecelakaan merupakan kejadian yang tidak dapat diduga dan tidak diharapkan. Kejadian yang tidak diduga terjadi karena tidak terdapat unsur kesengajaan atau perencanaan dan yang tidak diharapkan yatu adanya kerugian materil ataupun penderitaan yang dialami manusia dari skala paling rendah sampai paling tinggi. IMO (2007) dalam teorinya menyatakan bahwa bahaya (hazard) adalah sesuatu yang berpotensi mengancam jiwa manusia, kesehatan dan properti atau lingkungan. Penilaian dalam menentukan identifikasi konsekuensi kegagalan pada aktivitas patroli laut pengawasan SDKP di Pangkalan PSDKP Jakarta terhadap dampaknya bagi awak kapal yang terlibat dikelompokkan atas 5 (lima) jenis yaitu kelelahan, luka ringan, cedera ringan, cedera berat dan fatal.

Konsekuensi bahaya (severity) dikategorikan berdasarkan klasifikasi IMO (2007) yang mengklasifikasikan konsekuensi dari efeknya terhadap tubuh manusia mulai dari tidak berbahaya, ringan, menengah, berat dan fatal. Pengertian tidak berbahaya yaitu tidak ada efek kesehatan. Ringan yaitu luka ringan, membutuhkan penanganan langsung. Menengah yaitu cedera ringan, membutuhkan penanganan medis dokter/rumah sakit, membutuhkan waktu penyembuhan. Berat yaitu cedera berat/serius, mengakibatkan waktu penyembuhan hingga tidak masuk kerja. Fatal yaitu cacat tetap, dapat berakibat kehilangan nyawa.

Urutan aktivitas yang teridentifikasi menghasilkan urutan kegiatan dengan skenario dan plan pada patroli laut pengawasan SDKP di Pangkalan PSDKP Jakarta terdiri dari 5 (lima) tahap yang disajikan pada Tabel 1. Pada tahap - tahap aktivitas patroli pengawasan SDKP di laut diidentifikasi lebih lanjut sesuai sub-goal yang ingin dicapai. Pada tahap pertama adalah persiapan. Tahap ini memiliki 4 aktivitas utama dengan 18 sub aktivitas dengan total 49 OA. HTA dari tahap ini dapat dilihat pada Gambar 3. Konsekuensi kegagalan yang teridentifikasi dalam aktivitas patroli pengawasan SDKP di laut diurutkan dari yang terbesar yaitu cedera berat dengan persentase sebesar $38.10 \%$, kelelahan sebesar 25\%, fatal sebesar 15,48\%, luka ringan $14,29 \%$ dan cidera ringan $7.14 \%$. 
Tabel 1 Tahap aktivitas patroli pengawasan SDKP di laut

\begin{tabular}{cl}
\hline NO & \multicolumn{1}{c}{ Aktivitas } \\
\hline 1 & Persiapan \\
2 & Loading \\
3 & Pelayaran dan pengawasan di laut \\
4 & Penghentian, pemeriksaan dan penahanan kapal perikanan \\
5 & Kembali ke homebase \\
\hline
\end{tabular}

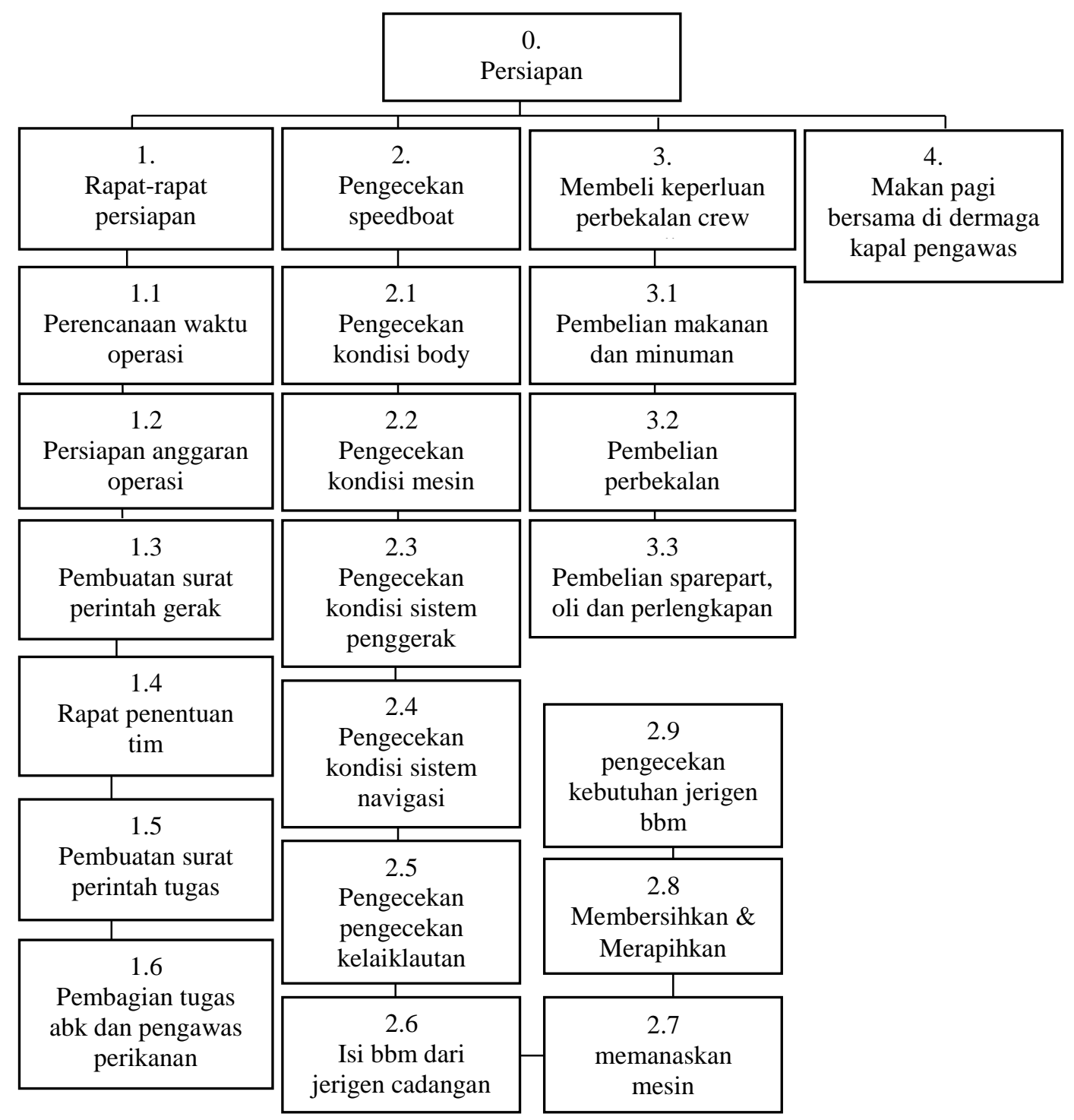

Gambar 3 HTA pada aktifitas persiapan 


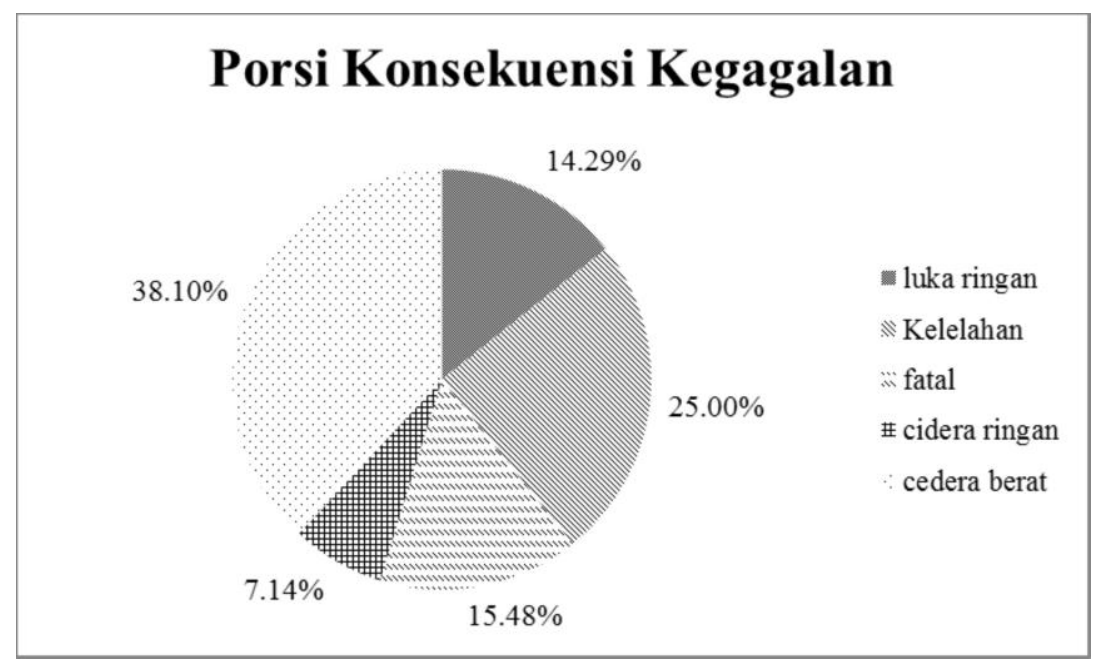

Gambar 4 Porsi konsekuensi kegagalan

Porsi konsekuensi kegagalan dapat dilihat pada Gambar 4. Tahap persiapan merupakan tahap awal dalam setiap patroli laut pengawasan SDKP. Aktivitas dimulai dengan rapat-rapat persiapan yang terdiri dari perencanaan waktu, persiapan anggaran, dan pembuatan surat-surat yang diperlukan dalam mendukung patroli laut pengawasan SDKP.

Pada tahap persiapan melibatkan beberapa orang, antara lain Nakhoda, koordinator operasi dan pimpinan unit kerja. Selanjutnya, dilakukan pengecekan kondisi speedboat yang dilakukan oleh juru mudi, teknisi mesin dan kelasi. Setelah jumlah personil yang terlibat patroli ditentukan, dilakukan pembelian perbekalan sesuai rencana yang telah ditetapkan.

Berdasarkan Tabel 2, potensi konsekuensi kegagalan yang dapat terjadi pada tahap persiapan antara lain kelelahan, luka ringan, cedera ringan dan cedera berat. Konsekuensi kelelahan terjadi pada 8 aktivitas, luka ringan terjadi pada 5 aktivitas, cedera ringan terjadi pada 2 aktivitas dan cedera berat terjadi pada 4 aktivitas. Konsekuensi kegagalan berupa cedera berat terjadi saat juru mesin melakukan pengecekan kondisi mesin speedboat pengawasan, ABK mengisi bahan bakar minyak (BBM) dari jerigen cadangan, juru mesin memanaskan mesin speedboat pengawasan, ABK membeli sparepart, oli dan perlengkapan speedboat. Peluang timbulnya konsekuensi dapat terjadi dan akan lebih banyak muncul apabila kegiatan perencanaan gagal dilakukan dengan baik (Handayani, et al. 2014). Tahap 2 (loading) merupakan aktivitas pemindahan seluruh akomodasi baik perbekalan kebutuhan patroli maupun pemindahan awak kapal dari darat yaitu dermaga ke atas speedboat pengawasan.

Tahap 2 memiliki 5 aktivitas utama dan 2 sub aktivitas dengan total 23 OA. HTA dari tahap ini dapat dilihat pada Gambar 5 . Aktivitas loading yang pertama dilakukan yaitu pengisian air tawar ke atas speedboat. Air tawar ditampung pada tangki air tawar dan jerigen cadangan air tawar. Selanjutnya yaitu pemindahan perbekalan, BBM dan Oli. Kemudian awak speedboat mulai dari nakhoda, pengawas perikanan dan awak lainnya.

Tabel 3 menunjukkan deskripsi kegagalan dan konsekuensi kegagalan yang dapat terjadi pada setiap sub aktivitas. Cedera berat dapat terjadi pada pengawas perikanan dan awak kapal lainnya pada saat mengangkat jerigen BBM dari dermaga ke atas speedboat pengawasan. Cedera berat dapat terjadi karena jerigen BBM terjatuh karena keterbatasan kemampuan awak kapal dan mengenai anggota tubuh ataupun karena kondisi pijakan dermaga dan speedboat licin sehingga awak speedboat terjatuh ke laut. Kegagalan yang lebih parah dapat terjadi jika jerigen tersebut bocor yang kemudian terbakar. Kondisi lingkungan yang buruk dan tidak mengenakan perlengkapan kerja yang lengkap menyebabkan kecelakaan 
Tabel 2 Identifikasi kegagalan pada tahap 1 (persiapan)

\begin{tabular}{|c|c|c|c|}
\hline Step & Task Description & Deskripsi Kegagalan & $\begin{array}{l}\text { Konsekuensi } \\
\text { kegagalan }\end{array}$ \\
\hline 0 & Persiapan & & \\
\hline 1 & Rapat-rapat persiapan & & \\
\hline 1.1 & Perencanaan waktu operasi & $\begin{array}{l}\text { Jadwal tidak cocok dan bentrok dengan kegiatan } \\
\text { lain/konflik kepentingan }\end{array}$ & Kelelahan \\
\hline 1.2 & Persiapan anggaran operasi & $\begin{array}{l}\text { Anggaran belum tersedia karena masalah } \\
\text { administrasi di KPPN }\end{array}$ & Kelelahan \\
\hline 1.3 & Pembuatan surat perintah gerak & $\begin{array}{l}\text { Pimpinan unit kerja tidak ada ditempat, target } \\
\text { operasi belum jelas }\end{array}$ & Kelelahan \\
\hline 1.4 & $\begin{array}{l}\text { Kapten, koordinator operasi dan } \\
\text { pimpinan rapat penentuan tim }\end{array}$ & $\begin{array}{l}\text { Rapat tidak sesuai jadwal dan terjadi konflik } \\
\text { kepentingan }\end{array}$ & Kelelahan \\
\hline 1.5 & $\begin{array}{l}\text { Koordinator operasi membuat } \\
\text { surat perintah tugas }\end{array}$ & $\begin{array}{l}\text { Kelengkapan administrasi belum lengkap, surat } \\
\text { berubah-ubah konsep }\end{array}$ & Kelelahan \\
\hline 1.6 & $\begin{array}{l}\text { Kapten melakukan membagian } \\
\text { tugas abk dan pengawas } \\
\text { perikanan }\end{array}$ & $\begin{array}{l}\text { Tugas dan fungsi masing-masing } \mathrm{ABK} \text { dan } \\
\text { pengawas perikanan tidak sesuai }\end{array}$ & Kelelahan \\
\hline 2 & $\begin{array}{l}\text { Pengecekan speedboat } \\
\text { pengawasan }\end{array}$ & & \\
\hline 2.1 & $\begin{array}{l}\text { ABK melakukan pengecekan } \\
\text { kondisi body speedboat } \\
\text { pengawasan }\end{array}$ & $\begin{array}{l}\text { Kondisi body kapal tidak baik (teritip, body } \\
\text { kapal bocor), pada saat perbaikan terpeleset, } \\
\text { anggota badan kena teritip }\end{array}$ & Luka ringan \\
\hline 2.2 & $\begin{array}{l}\text { Juru mesin melakukan } \\
\text { pengecekan kondisi mesin } \\
\text { speedboat pengawasan }\end{array}$ & $\begin{array}{l}\text { Mesin rusak (tidak bisa starter, mati sebelah, } \\
\text { propeler macet, mesin tidak bisa turun), } \\
\text { konsleting listrik, penempatan aki tidak } \\
\text { terlindung, mesin meledak }\end{array}$ & Cedera berat \\
\hline 2.3 & $\begin{array}{l}\text { Juru mesin dan ABK } \\
\text { pengecekan kondisi sistem } \\
\text { penggerak speedboat } \\
\text { pengawasan }\end{array}$ & $\begin{array}{l}\text { Hidrolik kemudi macet, pada saat perbaikan } \\
\text { kondisi lingkungan licin, dapat terjatuh }\end{array}$ & Luka ringan \\
\hline 2.4 & $\begin{array}{l}\text { Kapten melakukan pengecekan } \\
\text { kondisi sistem navigasi } \\
\text { speedboat pengawasan }\end{array}$ & $\begin{array}{l}\text { Sistem navigasi rusak, kabel dimakan tikus } \\
\text { terkelupas, konsleting listrik, pada saat } \\
\text { pengecekan antena terpeleset }\end{array}$ & Luka ringan \\
\hline 2.5 & $\begin{array}{l}\text { Kapten melakukan pengecekan } \\
\text { kelaiklautan speedboat } \\
\text { pengawasan }\end{array}$ & $\begin{array}{l}\text { Kerusakan dampra, kerusakan lifejacket, sistem } \\
\text { komunikasi karena alat rusak/dimakan } \\
\text { tikus/penempatan tidak baik }\end{array}$ & Luka ringan \\
\hline 2.6 & $\begin{array}{l}\text { ABK mengisi bbm dari jerigen } \\
\text { cadangan }\end{array}$ & $\begin{array}{l}\text { Jerigen bbm terjatuh menimpa anggota tubuh, } \\
\text { bbm tumpah/tercecer, kebakaran }\end{array}$ & Cedera berat \\
\hline 2.7 & $\begin{array}{l}\text { Juru mesin memanaskan mesin } \\
\text { speedboat pengawasan }\end{array}$ & $\begin{array}{l}\text { Konsleting listrik karena posisi aki tidak } \\
\text { terlindung, kapal meledak karena menyimpan } \\
\text { jerigen bbm tidak rapat, terbakar }\end{array}$ & Cedera berat \\
\hline 2.8 & $\begin{array}{l}\text { ABK membersihkan } \\
\text { keseluruhan speedboat }\end{array}$ & $\begin{array}{l}\text { Tempat pijakan licin (di atas kapal/di dermaga), } \\
\text { terjatuh }\end{array}$ & Luka ringan \\
\hline 2.9 & $\begin{array}{l}\text { Pengecekan kebutuhan jerigen } \\
\text { bbm yang dibawa untuk patroli }\end{array}$ & $\begin{array}{l}\text { Jerigen rusak, bocor sehingga harus membeli } \\
\text { jerigen baru }\end{array}$ & Kelelahan \\
\hline 3 & $\begin{array}{l}\text { Membeli keperluan perbekalan } \\
\text { crew speedboat pengawasan }\end{array}$ & & \\
\hline 3.1 & $\begin{array}{l}\text { Abk membeli makanan dan } \\
\text { minuman untuk makan pagi }\end{array}$ & $\begin{array}{l}\text { Jarak yang jauh dari dermaga, makanan dan } \\
\text { minuman terjatuh }\end{array}$ & Kelelahan \\
\hline 3.2 & $\begin{array}{l}\text { Abk membeli perbekalan pada } \\
\text { saat patroli }\end{array}$ & $\begin{array}{l}\text { Perbekalan banyak, abk tidak kuat membawa } \\
\text { perbekalan }\end{array}$ & Cedera ringan \\
\hline 3.3 & $\begin{array}{l}\text { Abk membeli sparepart, oli dan } \\
\text { perlengkapan speedboat }\end{array}$ & $\begin{array}{l}\text { Sparepart terlalu berat, abk tidak kuat membawa } \\
\text { sparepart, jatuh tertimpa sparepart }\end{array}$ & Cedera berat \\
\hline 4 & $\begin{array}{l}\text { Makan pagi bersama di dermaga } \\
\text { kapal pengawas }\end{array}$ & Dermaga licin atau rusak, terjatuh & Cedera ringan \\
\hline
\end{tabular}




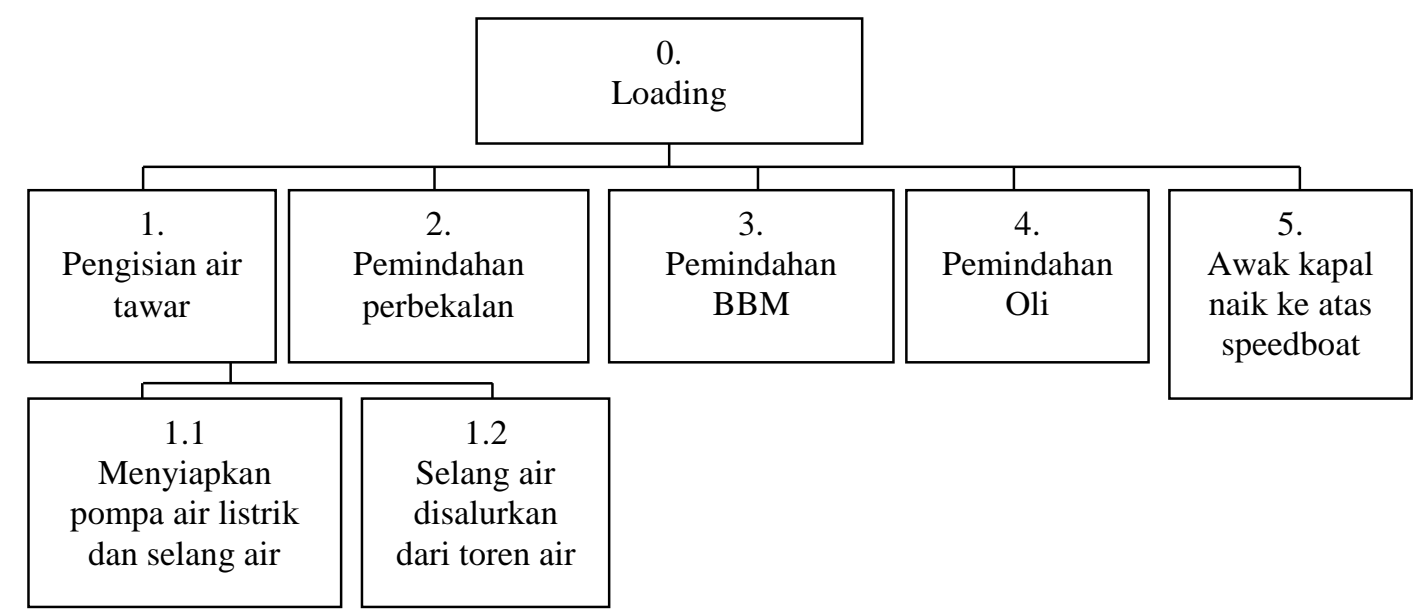

Gambar 5 HTA pada aktifitas loading

Tabel 3 Identifikasi kegagalan pada tahap 2 (loading)

\begin{tabular}{|c|c|c|c|}
\hline Step & Task Description & Deskripsi Kegagalan & $\begin{array}{c}\text { Konsekuensi } \\
\text { kegagalan }\end{array}$ \\
\hline 0 & Loading & & \\
\hline 1 & Mengisi air tawar & & \\
\hline 1.1 & $\begin{array}{l}\text { Abk menyiapkan pompa air listrik } \\
\text { dan selang air }\end{array}$ & $\begin{array}{l}\text { Kabel pompa listrik terbuka, tersengat } \\
\text { aliran listrik, konsleting }\end{array}$ & Cidera ringan \\
\hline 1.2 & $\begin{array}{l}\text { Selang air disalurkan dari toren air } \\
\text { di dermaga ke speedboat } \\
\text { pengawasan }\end{array}$ & Terlilit selang air, lantai licin/terpeleset & Luka ringan \\
\hline 2 & $\begin{array}{l}\text { Pengawas perikanan dan } \mathrm{ABK} \\
\text { memindahkan perbekalan dari } \\
\text { dermaga ke atas speedboat }\end{array}$ & $\begin{array}{l}\text { Kardus air minum/tempat perbekalan } \\
\text { jatuh ke laut, menimpa tubuh, perbekalan } \\
\text { rusak tidak dapat digunakan }\end{array}$ & Luka ringan \\
\hline 3 & $\begin{array}{l}\text { Pengawas perikanan dan } \mathrm{ABK} \\
\text { memindahkan jerigen bbm dari } \\
\text { dermaga ke atas speedboat }\end{array}$ & $\begin{array}{l}\text { Jerigen bbm jatuh ke laut, jerigen bocor, } \\
\text { menimpa anggota badan, bbm tercecer, } \\
\text { kebakaran }\end{array}$ & Cedera berat \\
\hline 4 & $\begin{array}{l}\text { ABK memindahkan oli dari } \\
\text { dermaga ke atas speedboat }\end{array}$ & $\begin{array}{l}\text { Dus/botol oli jatuh ke laut, menimpa } \\
\text { anggota badan, oli tumpah, pencemaran } \\
\text { perairan }\end{array}$ & Cedera ringan \\
\hline 5 & $\begin{array}{l}\text { Kapten, pengawas perikanan dan } \\
\text { ABK naik ke atas speedboat }\end{array}$ & $\begin{array}{l}\text { Kayu dermaga patah, pijakan kaki licin, } \\
\text { tergelincir }\end{array}$ & Cedera berat \\
\hline
\end{tabular}

kerja terjadi. Pada tahap ini cedera berat terjadi pada 2 aktivitas, cedera ringan 2 aktivitas dan luka ringan terjadi pada 2 aktivitas.

Tahap yang ketiga yaitu tahap pelayaran dan pengawasan di laut yang merupakan tahap yang paling banyak aktivitasnya yaitu sebanyak 7 aktivitas dan 18 sub-aktivitas dengan total 71 OA seperti terlihat pada Gambar 6.

Aktivitas pelayaran dan pengawasan di laut merupakan aktivitas inti dari patroli pengawasan SDKP di laut. Aktivitas dimulai dengan bertolak dari kapal pengawas di
Pelabuhan Perikanan Samudera Nizam Zachman Jakarta menuju SPBU di Pelabuhan Marina Ancol. Setelah mengisi BBM dilanjutkan dengan berlayar menuju laut untuk melakukan aktivitas pengawasan terhadap kapal-kapal perikanan yang sedang beroperasi. Selama pelayaran dilakukan pengintaian atau pengamatan dari speedboat tentang keberadaan kapal-kapal perikanan yang akan diperiksa. Pengintaian bertahap dilakukan dari haluan, kemudian dari dalam speedboat dengan menggunakan teropong ataupun mata telanjang dan di bagian buritan. 


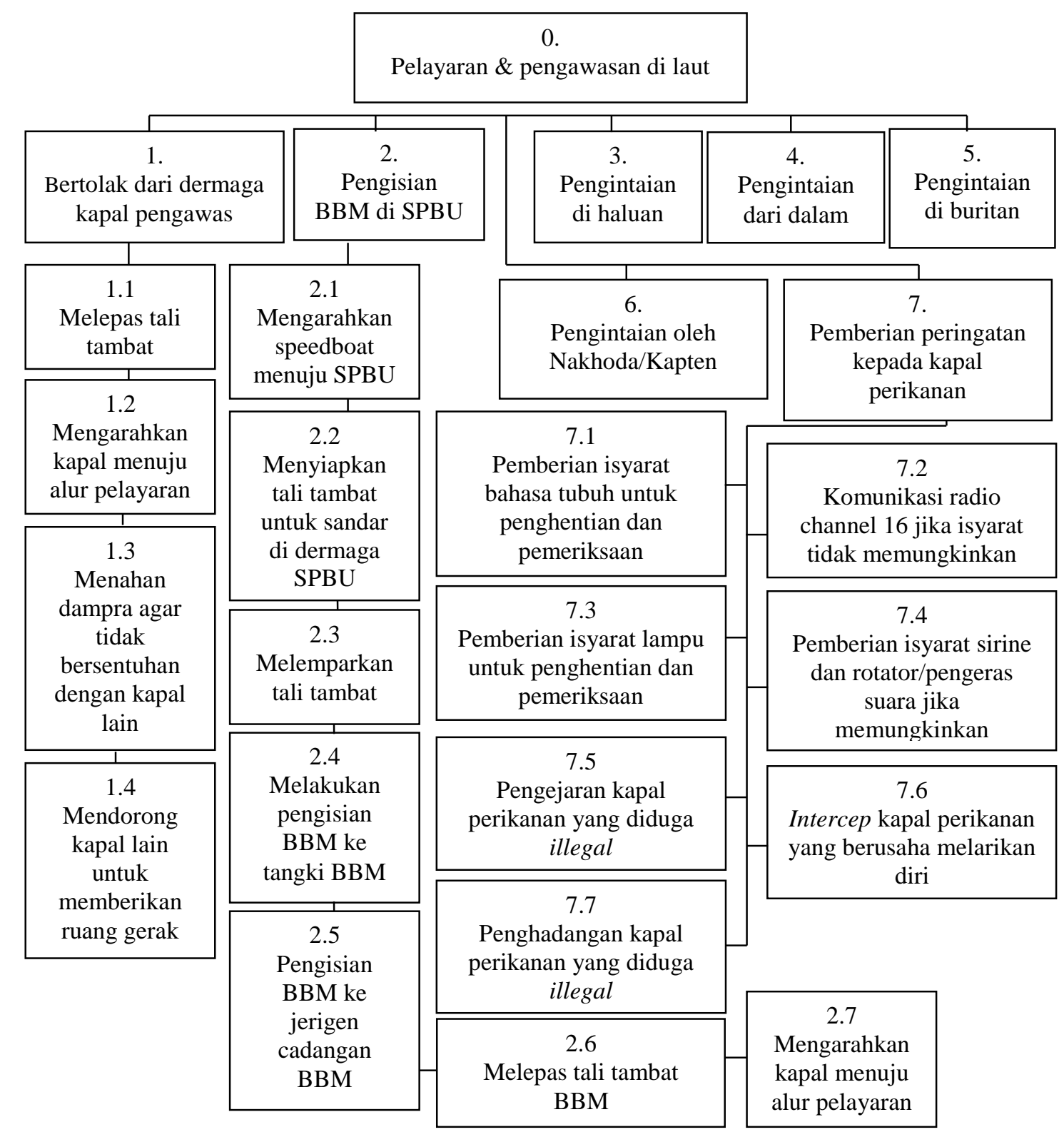

Gambar 6 HTA pada aktifitas pelayaran dan pengawasan di laut

Pengintaian dan pengamatan di haluan dan buritan dilakukan oleh pengawas perikanan, sedangkan di dalam speedboat dilakukan oleh Nakhoda. Jika pada saat pengintaian dan pengawasan terlihat kapal perikanan yang sedang beroperasi, maka Nakhoda speedboat pengawasan memberikan perintah berupa peringatan kepada kapal perikanan untuk dilakukan pemeriksaan oleh pengawas perikanan. Aktivitas pelayaran dan pengawasan di laut ini penuh dengan risiko dan ketidakpastian yang dapat menyebabkan terjadinya kecelakaan kerja. Deskripsi kegagalan dan konsekuensi kegagalan dapat dilihat pada Tabel 4 .

Berdasarkan tabel 4, dapat diidentifikasi peluang risiko kegagalan pada seluruh sub akitivitas pelayaran dan pengawasan di laut. Konsekuensi kegagalan berupa kelelahan dapat terjadi pada 3 aktivitas, luka ringan dapat terjadi pada 4 aktivitas, cedera ringan dapat terjadi hanya pada 1 aktivitas, cedera berat dapat terjadi pada 4 aktivitas dan fatal dapat terjadi pada 10 aktivitas. Tahap 3 merupakan tahap dengan konsekuensi kegagalan terbesar dibandingkan dengan tahap lainnya. 
Tabel 4 Identifikasi kegagalan pada tahap 3 (Pelayaran dan pengawasan di laut)

\begin{tabular}{|c|c|}
\hline Step & Task Description \\
\hline 0 & Pelayaran, pengawasan di laut \\
\hline 1 & Bertolak dari dermaga kapal pes \\
\hline 1.1 & $\begin{array}{l}\text { ABK dan pengawas perikanan } \\
\text { melepas tali tambat }\end{array}$ \\
\hline 1.2 & $\begin{array}{l}\text { Kapten mengarahkan kapal } \\
\text { menuju alur pelayaran }\end{array}$ \\
\hline 1.3 & $\begin{array}{l}\text { Pengawas perikanan dan ABK } \\
\text { menahan dampra agar tidak } \\
\text { bersentuhan dengan kapal lain }\end{array}$ \\
\hline 1.4 & $\begin{array}{l}\text { Pengawas perikanan dan } \mathrm{ABK} \\
\text { mendorong kapal lain untuk } \\
\text { memberikan ruang gerak }\end{array}$ \\
\hline
\end{tabular}

2 Pengisian BBM di SPBU pantai marina ancol

2.1 Kapten mengarahkan speedboat menuju SPBU di dermaga marina Ancol

2.2 ABK dan pengawas perikanan menyiapkan tali tambat untuk sandar di dermaga SPBU

2.3 Melemparkan tali tambat untuk sandar di SPBU

Terpeles

Terpeleset/terjatuh, anggota tubuh telilit tali tambat, anggota tubuh terjepit antara kapal dengan dermaga

Kapal tabrakan dengan kapal lain, kapal hancur, abk terjatuh/terjepit

Cedera berat

Anggota badan terlilit tali dampra,

dampra terjatuh, anggota badan terjepit Fatal

kapal lain

ABK dan pengawas perikanan terjatuh, terjepit kapal lain

Konsekuensi

kegagalan

Fatal

Fatal

Speedboat terkena ombak/gelombang/kecelakaan

Fatal

Terlilit tali tambat, lantai deck licin, terjatuh

Luka ringan

Terlilit tali tambat, terpeleset

Luka ringan

2.4 ABK dan petugas SPBU melakukan pengisian BBM ke tangki BBM

2.5 ABK dan petugas SPBU melakukan pengisian BBM ke jerigen cadangan BBM

2.6 ABK dan pengawas perikanan melepas tali tambat

Selang bbm bocor, bbm tumpah, terbakar

Cedera berat

Selang bbm bocor, bbm tumpah, terbakar, jerigen bocor, jerigen terjatuh

Cedera berat

Anggota tubuh terkena tali tambat yang dilempar

2.7 Kapten mengarahkan kapal menuju alur pelayaran

Tabrakan dengan kapal lain

Luka ringan

Fatal

Kapal terkena gelombang, awak kapal terjatuh karena tidak berpegangan, alat pengintai jatuh ke laut

berjaga bergantian di haluan depan untuk pengintaian

4 Pengawas perikanan dan ABK berjaga di dalam cabin untuk pengintaian

5 Pengawas perikanan dan ABK berjaga di buritan untuk pengintaian

Mabuk laut karena berada didalam kapal menggunakan teropong

Kelelahan

Kapal terkena gelombang, awak kapal terjatuh karena tidak berpegangan, alat pengintai jatuh ke laut

Fatal

6 Kapten memantau menggunakan radar/teropong terhadap kapal perikanan yang

Radar rusak, cuaca buruk, konsentrasi dan stamina menurun

Kelelahan mencurigakan

7 Pemberian peringatan kapal perikanan untuk berhenti

7.1 Pemberian isyarat bahasa tubuh untuk penghentian dan pemeriksaan

7.2 Komunikasi radio channel 16 jika isyarat tidak memungkinkan

Isyarat tidak dipedulikan, kapal goyang, abk dan pengawas perikanan yang berada Cedera berat diatas kapal jatuh

Komunikasi radio terputus karena rusak/eror

Kelelahan

Konsleting listrik, pada saat perbaikan kesetrum

Cedera ringan untuk penghentian dan pemeriksaan 


\begin{tabular}{clll}
\hline Step & \multicolumn{1}{c}{ Task Description } & \multicolumn{1}{c}{ Deskripsi Kegagalan } & $\begin{array}{c}\text { Konsekuensi } \\
\text { kegagalan }\end{array}$ \\
\hline 7.4 & $\begin{array}{l}\text { Pemberian isyarat sirine dan } \\
\text { rotator/pengeras suara jika } \\
\text { memungkinkan }\end{array}$ & $\begin{array}{l}\text { Konsleting listrik, pengeras suara tidak } \\
\text { terkendali, bising }\end{array}$ & Luka ringan \\
7.5 & $\begin{array}{l}\text { Pengejaran kapal perikanan } \\
\text { yang diduga ilegal }\end{array}$ & $\begin{array}{l}\text { Cuaca buruk, gelombang tinggi, badai, } \\
\text { mesin mogok, kecelakaan }\end{array}$ & Fatal \\
7.6 & $\begin{array}{l}\text { Intercep kapal perikanan yang } \\
\text { berusaha melarikan diri }\end{array}$ & Perlawanan dari kapal lain, tabrakan kapal & Fatal \\
7.7 & $\begin{array}{l}\text { Penghadangan kapal perikanan } \\
\text { yang diduga ilegal }\end{array}$ & Kapal tidak mau berhenti, tabrakan kapal & Fatal \\
\hline
\end{tabular}

Hal ini disebabkan karena beberapa hal, yaitu kondisi alam yang cepat berubah dari prediksi awal seperti arus, gelombang, angin, suhu udara dan cuaca. Selain faktor cuaca beberapa kondisi yang menyebabkan munculnya kegagalan yaitu operator yang kurang berpengalaman seperti baru memenuhi kualifikasi namun tidak expert, alat yang tidak dapat diandalkan seperti alat navigasi rusak, mesin gagal berfungsi, tali tambat dan dampra yang sudah lapuk.

Aktivitas yang sangat berisiko pada tahap 3 pelayaran dan pengawasan di laut memiliki konsekuensi kegagalan dengan kategori fatal. Aktivitas pengejaran kapal perikanan yang diduga illegal termasuk kedalam kategori fatal dengan deskripsi kegagalan yaitu karena cuaca buruk, gelombang tinggi ataupun terkena badai yang tidak dapat diantisipasi oleh speedboat dengan kualifikasi sea state 3 diikuti dengan mesin speedboat mati. Hal ini dapat menyebabkan kecelakaan yang berakibat fatal. Aktivitas lain yang masuk kategori fatal yaitu pada saat kapten/Nakhoda mengarahkan kapal menuju alur pelayaran yang disebabkan karena tabrakan dengan kapal lain. Kondisi ini dapat terjadi karena ketidakmampuan alat berfungsi dengan optimal dan kondisi perairan disekitar teluk Jakarta yang padat dan merupakan alur pelayaran yang sangat ramai dilalui berbagai jenis kapal.

Konsekuensi kegagalan dengan kategori cedera berat dapat terjadi pada aktivitas pengisian BBM oleh awak kapal dan petugas SPBU dimana pengisian BBM dilakukan pada tangki speedboat yang bergerak dan tidak stabil sehingga dapat menyebabkan
BBM tumpah dan terbakar yang kemudian dapat meledakkan speedboat. Selain pengisian pada tangki BBM, pengisian juga dilakukan menggunakan jerigen cadangan yang memiliki risiko terbakar sangat tinggi karena kondisi jerigen yang tidak didesain khusus untuk mengangkut BBM dan ditempatkan di palka bagian haluan (posisi yang paling tidak stabil).

Cedera ringan dialami pada aktivitas pemberian isyarat lampu untuk penghentian dan pemeriksaan, umumnya dilakukan malam hari. Risiko yang dialami terjadi jika kondisi lampu tidak berfungsi yang kemudian dilakukan perbaikan terjadi konsleting listrik yang dapat mencederai awak kapal. Kondisi tersebut dapat terjadi karena sedikit atau tidak ada pengecekan independen atau percobaan pada hasil. Seharusnya kapal-kapal milik pemerintah dapat diperiksa oleh pihak auditor independen agar tetap layak beroperasi dan meminimalisir terjadinya kegagalan yang pada akhirnya melindungi awak kapal yang terlibat dalam kegiatan patroli menggunakan $\mathrm{kapal} /$ speedboat.

Peluang konsekuensi kegagalan berupa cidera ringan dapat terjadi pada aktivitas melemparkan tali tambat untuk sandar di dermaga SPBU atau dermaga lainnya. Deskripsi kegagalan yang terjadi yaitu awak kapal terlilit tali tambat dan terjatuh. Hal ini dapat terjadi akibat adanya dorongan untuk menggunakan prosedur yang berbahaya, seperti tidak menempatkan tali tambat pada tempatnya dan adanya pembiaran tali tambat tercecer dilantai deck.

Anggota tubuh dapat terkena tali tambat yang dilempar pada aktivitas melepas tali tambat dari dermaga ataupun pada saat 
tambat pada kapal lain. Konsekuensi kegagalan yang dapat terjadi yaitu awak kapal mengalami luka ringan. Hal ini dapat disebabkan karena operator yang kurang berpengalaman seperti baru memenuhi kualifikasi namun tidak expert. Kemudian untuk konsekuensi kegagalan berupa kelelahan terjadi pada aktivitas dengan intensitas yang sering dan dilakukan pada kondisi lingkungan kerja yang tidak stabil, contohnya yaitu awak kapal baik
ABK atau pengawas perikanan melakukan aktivitas pengintaian baik di haluan maupun buritan dengan teropong, dilakukan pada saat speedboat bergerak dan dilakukan sepanjang perjalanan di laut sampai menemukan kapal perikanan yang akan diperiksa. Hal ini tentu saja menguras tenaga ditambah dengan terpaan sinar matahari yang sangat terik pada siang hari dan tiupan angin dingin pada malam hari.



Gambar 7 HTA pada aktifitas pelayaran dan pengawasan di laut 
Tahap selanjutnya yaitu tahap 4 dengan aktvitas utama yatu penghentian, pemeriksaan dan penahanan kapal perikanan. Tahap 4 ini terdiri dari 4 aktivitas utama dan 20 sub aktivitas dengan total 45 OA. Tahap ini dilakukan setelah pengawas perikanan melakukan pengintaian dan mendapatkan target kapal perikanan yang akan diperiksa dan diawasi kegiatannya. Aktivitas penghentian, pemeriksaan dan penahanan kapal dapat dilihat pada Gambar 7.

Aktivitas penghentian, pemeriksaan dan penahanan kapal perikanan merupakan tindak lanjut dari aktivitas sebelumnya yaitu pelayaran dan pengawasan di laut. Hasil dari pengintaian selama pelayaran didapatkan kapal perikanan yang sedang beroperasi melakukan penangkapan atau pengangkutan ikan di laut. Aktivitas pertama dalam tahap ini yaitu speedboat pengawasan tambat pada kapal perikanan yang akan diperiksa. Sebelum kapal benar-benar tambat, awak speedboat memberikan isyarat kepada awak kapal perikanan yang diperiksa bahwa speedboat akan tambat pada sisi bagian kanan/kiri kapal perikanan. Dalam sub aktivitas ini risiko yang dihadapi awak kapal terjatuh karena kapal miring/oleng terkena gelombang yang tiba-tiba terbentuk akibat speedboat dan kapal perikanan berdekatan. Konsekuensi kegagalan yang dialami yaitu cedera berat.

Awak speedboat pengawasan melemparkan tali tambat ke kapal perikanan untuk persiapan tambat dengan konsekuensi kegagalan dengan kategori fatal karena anggota tubuh awak speedboat terlilit tali tambat dan terjatuh ke laut. Hal ini terjadi karena adanya dorongan untuk melakuan prosedur yang berbahaya dimana tali tambat tidak ditata sedemikian rupa sehingga membahayakan awak speedboat pengawasan. Konsekuensi kegagalan dan deskripsi kegagalan pada aktivitas tahap 4 yaitu penghentian, pemeriksaan dan penahanan kapal perikanan dapat dilihat pada Tabel 5.

Aktivitas utama dimana speedboat pengawasan tambat pada kapal perikanan yang akan diperiksa merupakan aktivitas dengan

Tabel 5 Identifikasi kegagalan pada tahap 4 (penghentian, pemeriksaan dan penahanan kapal perikanan)

\begin{tabular}{rlll}
\hline \multicolumn{1}{c}{ Step } & \multicolumn{1}{c}{ Task Description } & \multicolumn{1}{c}{ Deskripsi Kegagalan } & \multicolumn{1}{c}{$\begin{array}{c}\text { Konsekuensi } \\
\text { kegagalan }\end{array}$} \\
\hline 1 & $\begin{array}{l}\text { Speedboat pengawasan tambat di kapal yang akan diperiksa } \\
\text { Pengawas perikanan dan abk } \\
\text { memberikan isyarat untuk tambat } \\
\text { di kapal yang akan diperiksa }\end{array}$ & $\begin{array}{l}\text { Kapal terkena gelombang tiba-tiba, } \\
\text { kapal miring, abk dan pengawas } \\
\text { perikanan terjatuh }\end{array}$ & Cedera berat \\
1.2 & $\begin{array}{l}\text { Abk dan pengawas perikanan } \\
\text { melemparkan tali tambat ke kapal }\end{array}$ & $\begin{array}{l}\text { Anggota badan terlilit tali tambat dan } \\
\text { jatuh ke laut }\end{array}$ & Fatal \\
& $\begin{array}{l}\text { lain } \\
\text { Abk dan pengawas perikanan } \\
\text { menarik tali tambat agar kapal } \\
\text { patroli berdampingan }\end{array}$ & $\begin{array}{l}\text { Anggota badan terjepit, terpeleset } \\
\text { akibat benturan kapal }\end{array}$ & Cedera berat \\
1.4 & $\begin{array}{l}\text { Abk dan pengawas perikanan } \\
\text { melompat ke kapal yang akan } \\
\text { diperiksa }\end{array}$ & $\begin{array}{l}\text { Pijakan kaki licin, } \\
\text { terpeleset/terjatuh/terjepit }\end{array}$ & Fatal \\
2.1 & $\begin{array}{l}\text { Pemeriksaan kapal perikanan } \\
\text { Pengawas perikanan memeriksa } \\
\text { kelengkapan dan kesesuaian } \\
\text { dokumen kapal }\end{array}$ & $\begin{array}{l}\text { Mabuk laut, cuaca panas, menulis di } \\
\text { atas kapal yang bergerak-gerak } \\
\text { menyebabkan sakit kepala }\end{array}$ & Kelelahan \\
2.2 & $\begin{array}{l}\text { Pengawas perikanan memeriksa } \\
\text { seluruh ruangan di kapal } \\
\text { (palka,ruang penyimpanan } \\
\text { lainnya) }\end{array}$ & $\begin{array}{l}\text { Deck kapal licin, terjatuh, tersangkut } \\
\text { jaring, peralatan di atas kapal jatuh } \\
\text { mengenai anggota badan }\end{array}$ & Cedera berat \\
$\begin{array}{l}\text { Pengawas perikanan memeriksa } \\
\text { kesesuaian alat tangkap }\end{array}$ & $\begin{array}{l}\text { Deck kapal licin, terjatuh, tersangkut } \\
\text { jaring, peralatan di atas kapal jatuh } \\
\text { mengenai anggota badan }\end{array}$ & Cedera berat \\
\hline
\end{tabular}




\begin{tabular}{|c|c|c|c|}
\hline Step & Task Description & Deskripsi Kegagalan & $\begin{array}{c}\text { Konsekuensi } \\
\text { kegagalan }\end{array}$ \\
\hline 2.4 & $\begin{array}{l}\text { Pengawas perikanan memeriksa } \\
\text { palka dan kesesuaian hasil } \\
\text { tangkapan }\end{array}$ & $\begin{array}{l}\text { Peralatan kerja jatuh ke palka, licin } \\
\text { sehingga terpeleset }\end{array}$ & Cedera ringan \\
\hline 2.5 & $\begin{array}{l}\text { Pengawas perikanan memeriksa } \\
\text { ruang mesin }\end{array}$ & $\begin{array}{l}\text { Ruang mesin panas, anggota badan } \\
\text { menyentuh knalpot, menghirup udara } \\
\text { kotor }\end{array}$ & Cedera berat \\
\hline 2.6 & $\begin{array}{l}\text { Pengawas perikanan memeriksa } \\
\text { call sign dan tanda selar }\end{array}$ & $\begin{array}{l}\text { Mabuk laut, cuaca panas, menulis di } \\
\text { atas kapal yang bergerak-gerak } \\
\text { menyebabkan sakit kepala }\end{array}$ & Kelelahan \\
\hline 2.7 & $\begin{array}{l}\text { Pengawas perikanan mengisi } \\
\text { form pemeriksaan }\end{array}$ & $\begin{array}{l}\text { Mabuk laut, cuaca panas, menulis di } \\
\text { atas kapal yang bergerak-gerak } \\
\text { menyebabkan sakit kepala }\end{array}$ & Kelelahan \\
\hline 3 & Pemberian tindakan & & \\
\hline 3.1 & $\begin{array}{l}\text { Pengawas perikanan melepaskan } \\
\text { kapal perikanan dan melanjutkan } \\
\text { perjalanan (jika tidak ada } \\
\text { pelanggaran) }\end{array}$ & $\begin{array}{l}\text { Mabuk laut, cuaca panas, menulis di } \\
\text { atas kapal yang bergerak-gerak } \\
\text { menyebabkan sakit kepala }\end{array}$ & Kelelahan \\
\hline 3.2 & $\begin{array}{l}\text { Pengawas perikanan memberikan } \\
\text { dugaan pelanggaran kepada ppns } \\
\text { perikanan }\end{array}$ & $\begin{array}{l}\text { Komunikasi terganggu karena alat } \\
\text { rusak, terombang-ambing diatas kapal }\end{array}$ & Kelelahan \\
\hline 3.3 & $\begin{array}{l}\text { Ppns perikanan memberikan } \\
\text { informasi pelanggaran kepada } \\
\text { nakhoda kapal perikanan yang } \\
\text { diperiksa }\end{array}$ & $\begin{array}{l}\text { Adanya perlawanan fisik/verbal dari } \\
\text { abk kapal perikanan yang diperiksa }\end{array}$ & Cedera berat \\
\hline 3.4 & $\begin{array}{l}\text { Ppns perikanan memberikan } \\
\text { tindakan sesuai pelanggaran }\end{array}$ & $\begin{array}{l}\text { Adanya perlawanan fisik/verbal dari } \\
\text { abk kapal perikanan yang diperiksa }\end{array}$ & Cedera berat \\
\hline 3.5 & $\begin{array}{l}\text { Ppns perikanan menyita alat } \\
\text { tangkap yang dilarang digunakan } \\
\text { (trawl,pukat berkantong,dll) }\end{array}$ & $\begin{array}{l}\text { Pada saat memindahkan alat tangkap, } \\
\text { anggota badan tertimpa alat tangkap, } \\
\text { terlilit, terjepit }\end{array}$ & Cedera berat \\
\hline 3.6 & $\begin{array}{l}\text { Ppns perikanan menyita dokumen } \\
\text { kapal perikanan untuk di adhoc }\end{array}$ & $\begin{array}{l}\text { Adanya perlawanan fisik/verbal dari } \\
\text { abk/nakhoda kapal perikanan yang } \\
\text { diperiksa }\end{array}$ & Cedera berat \\
\hline 3.7 & $\begin{array}{l}\text { Abk dan pengawas perikanan } \\
\text { mengawal kapal perikanan yang } \\
\text { akan di adhoc di atas kapal } \\
\text { perikanan yang di adhoc }\end{array}$ & $\begin{array}{l}\text { Tidak mengetahui navigasi ke } \\
\text { homebase, tersesat, adanya perlawanan }\end{array}$ & Cedera berat \\
\hline 3.8 & $\begin{array}{l}\text { Memindahkan abk kapal } \\
\text { perikanan yang diadhoc ke } \\
\text { speedboat pengawasan }\end{array}$ & $\begin{array}{l}\text { Terpeleset karena lantai deck licin, } \\
\text { kapal goyang }\end{array}$ & Luka ringan \\
\hline 3.9 & $\begin{array}{l}\text { Abk dan pengawas perikanan } \\
\text { mengatur posisi peletakan alat } \\
\text { tangkap sitaan di atas kapal } \\
\text { patroli }\end{array}$ & $\begin{array}{l}\text { Abk dan pengawas perikanan terlilit } \\
\text { jaring, anggota badan tertimpa } \\
\text { perlengkapan alat tangkap }\end{array}$ & Cedera berat \\
\hline 4 & $\begin{array}{l}\text { Abk dan pengawas perikanan } \\
\text { mendokumentasikan setiap } \\
\text { kegiatan }\end{array}$ & $\begin{array}{l}\text { Alat dokumentasi rusak, terjatuh, } \\
\text { petugasnya mabuk laut }\end{array}$ & Kelelahan \\
\hline
\end{tabular}

risiko konsekuensi kegagalan dengan kategori fatal yang paling banyak terjadi pada sub aktivitasnya yaitu sebesar 50\%. Aktivitas ini merupakan aktivitas kritis yang terjadi pada patroli pengawasan SDKP di laut. Kesalahan posisi tubuh, tidak mengenakan perlengkapan keselamatan dan keputusan awak speedboat pengawasan melakukan tindakan berbahaya terjadi tanpa disadari demi keberhasilan satu kegiatan.

Aktivitas selanjutnya yaitu pemeriksaan kapal perikanan oleh pengawas perikanan. Pemeriksaan kapal perikanan meliputi pemeriksaan kesesuaian dokumen diatas kapal 
dengan dokumen yang tertera pada ijin yang dikeluarkan oleh instansi terkait. Pemeriksaan alat tangkap dilakukan dengan pemeriksaan fisik alat tangkap yang kemudian dibandingkan dengan ijin yang tertuang dalam Surat Ijin Penangkapan/Pengangkutan Ikan (SIPI/ SIKPI). Pemeriksaan nomor mesin, jenis hasil tangkapan, volume palka dan tanda selar kapal dilakukan satu per satu yang kemudian dituangkan dalam form pemeriksaan kapal perikanan. Jika tidak ada indikasi pelanggaran, maka kapal perikanan dipersilahkan melanjutkan operasi penangkapan ikan.

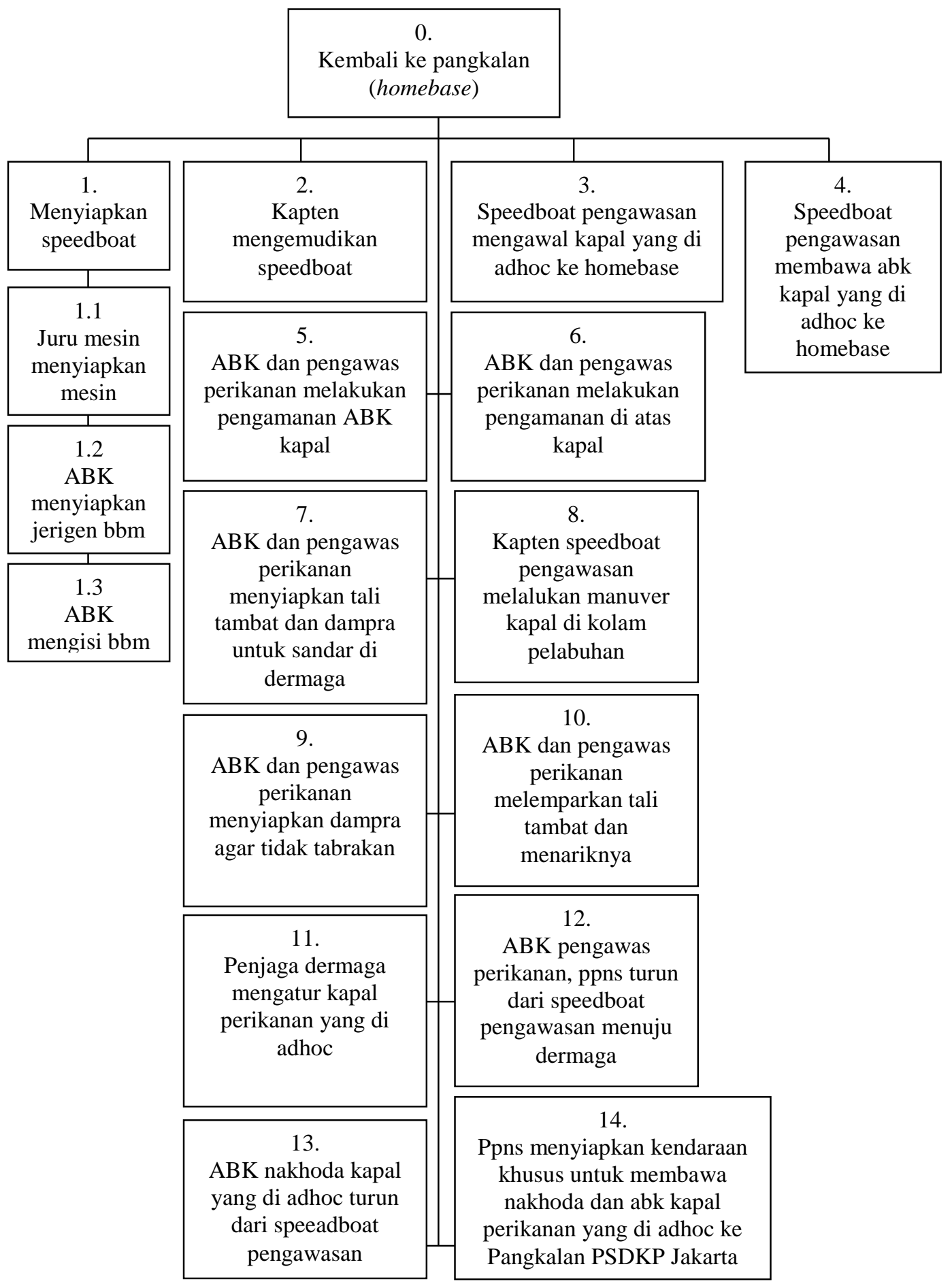

Gambar 8 HTA pada aktifitas kembali ke pangkalan 
Namun jika terbukti melakukan tindakan yang melanggar peraturan perundang-undangan yang berlaku, maka Penyidik Pegawai Negeri Sipil (PPNS) Perikanan memberikan tindakan.

Aktivitas-aktivitas yang dilakukan awak speedboat pengawasan didokumentasikan secara bertahap mulai dari persiapan sampai dengan kembali ke pangkalan, untuk itu aktivitas mendokumentasikan kegiatan dikategorikan aktivitas sekunder yang artinya aktivitas ini tidak harus dilakukan sesuai urutan kegiatan. Tahap terakhir yaitu tahap 5 kembali ke pangkalan yang terdiri dari 14 aktivitas utama dan 3 sub aktivitas. Tahap ini merupakan tindak lanjut dan rangkaian dari aktivitas sebelumnya yang dimulai dengan mempersiapkan speedboat untuk siap kembali ke pangkalan. Aktivitas tahap 5 dapat dilihat pada Gambar 8.

Aktivitas yang disiapkan yaitu mempersiapkan mesin agar kondisi mesin tetap prima, menyiapkan jerigen BBM dan mengisi BBM dari jerigen cadangan. Setelah speedboat pengawasan siap, kapten mengemudikan speedboat menuju pangkalan. Jika pada saat patroli pengawasan SDKP di laut menemukan kapal yang diduga melakukan pelanggaran dan diperintahkan adhoc oleh PPNS, maka speedboat harus mengawal kapal perikanan tersebut sampai pangkalan. Pada saat mengawal kapal perikanan yang di adhoc, ABK kapal perikanan tersebut dipindahkan ke speedboat pengawasan dan pengawas perikanan dan awak speedboat pengawasan mengawal kapal perikanan tersebut bersamasama speedboat pengawasan menuju pangkalan.

Setelah memasuki kawasan Pelabuhan Perikanan Samudera Nizam Zachman Jakarta dan mendekati dermaga kapal pengawas, kapten/Nakhoda harus melakukan manuver di kolam pelabuhan agar tidak saling berbenturan. Sementara itu awak speedboat mempersiapkan tali tambat untuk tambat di dermaga. Setelah tambat awak speedboat beserta seluruh awak kapal perikanan yang diadhoc dipersiapkan untuk dibawa ke Pangkalan PSDKP Jakarta untuk diperiksa lebih lanjut. Dengan tibanya seluruh awak kapal di dermaga kapal pengawas maka berakhirlah seluruh aktivitas patroli pengawasan SDKP di laut.

Pada tahap 5 ini konsekuensi kegagalan yang terjadi adalah kelelahan dan cedera berat dan fatal. hal tersebut disebabkan karena beberapa faktor, yaitu adanya dorongan untuk menggunakan prosedur yang berbahaya seperti pada aktivitas penyiapan jerigen BBM menggunakan jerigen yang tidak didesain khusus untuk mengangkut BBM, tutup jerigen yang hanya menggunakan plastic dan diikat karet, penyimpanan diletakkan di haluan yang merupakan bagian speedboat yang sangat tidak stabil dan dapat mengakibatkan BBM tumpah. Faktor lain yaitu ketidakbiasaan atau tidak memahami terhadap sebuah situasi yang sebenarnya penting namun jarang terjadi seperti pada aktivitas speedboat pengawasan mengawal kapal yang di adhoc ke pangkalan dimana speedboat terkena gelombang yang tinggi diluar kualifikasi sea state 3 yang menyebabkan kapal oleng dan tenggelam.

Faktor berikutnya yaitu ketidakkonsistenan dari tampilan atau prosedur seperti pada aktivitas awak speedboat pengawasan mengisi BBM speedboat pada saat disiapkan kembali ke pangkalan, prosedur seperti penempatan tidak pada posisi yang stabil, tidak mengenakan perlengkapan dan tidak mempersiapkan peralatan keselamatan dan yang paling berbahaya adalah merokok diatas tempat penyimpanan BBM merupakan beberapa aktivitas yang penuh dengan risiko dan dapat meningkatkan kecelakaan kerja. Pada Tabel 6 ditampilkan konsekuensi kegagalan pada tahap 5 yaitu kembali ke pangkalan.

\section{SIMPULAN DAN SARAN}

Berdasarkan analisis yang dilakukan dalam penelitian ini, maka dapat disimpulkan bahwa :

1. Aktivitas yang teridentifikasi pada patroli pengawasan SDKP di laut yang dilakukan oleh pengawas perikanan di Pangkalan PSDKP Jakarta yaitu 84 aktivitas. Aktivitas 
Tabel 6 Identifikasi kegagalan pada tahap 5

\begin{tabular}{|c|c|c|c|}
\hline Step & Task Description & Deskripsi Kegagalan & $\begin{array}{c}\text { Konsekuensi } \\
\text { kegagalan }\end{array}$ \\
\hline 0 & Kembali ke pangkalan & & \\
\hline 1 & Menyiapkan speedboat & & \\
\hline 1.1 & $\begin{array}{l}\text { Juru mesin menyiapkan mesin kapal } \\
\text { untuk kembali ke homebase }\end{array}$ & $\begin{array}{l}\text { Mesin mati/mogok, kapal terombang- } \\
\text { ambing }\end{array}$ & Kelelahan \\
\hline 1.2 & $\begin{array}{l}\text { Abk menyiapkan jerigen bbm untuk diisi } \\
\text { pada kapal patroli }\end{array}$ & $\begin{array}{l}\text { Jerigen terjatuh mengenai anggota } \\
\text { tubuh, bbm tumpah/terbakar }\end{array}$ & $\begin{array}{l}\text { Cedera } \\
\text { berat }\end{array}$ \\
\hline 1.3 & $\begin{array}{l}\text { Abk mengisi bbm kapal untuk kembali } \\
\text { ke home base }\end{array}$ & Bbm tumpah, terbakar & $\begin{array}{l}\text { Cedera } \\
\text { berat }\end{array}$ \\
\hline 2 & Kapten mengemudikan speedboat & $\begin{array}{l}\text { Melakukan kegiatan yang monoton } \\
\text { dalam waktu yang lama }\end{array}$ & Kelelahan \\
\hline 3 & $\begin{array}{l}\text { Speedboat pengawasan mengawal kapal } \\
\text { yang di adhoc ke homebase }\end{array}$ & $\begin{array}{l}\text { Kapal terkena gelombang } \\
\text { tinggi/kecelakaan, kabar tabrakan }\end{array}$ & Fatal \\
\hline 4 & $\begin{array}{l}\text { Speedboat pengawasan membawa abk } \\
\text { kapal yang di adhoc ke homebase }\end{array}$ & $\begin{array}{l}\text { Adanya perlawanan fisik/verbal, kapal } \\
\text { dibajak }\end{array}$ & $\begin{array}{l}\text { Cedera } \\
\text { berat }\end{array}$ \\
\hline 5 & $\begin{array}{l}\text { ABK dan pengawas perikanan } \\
\text { melakukan pengamanan ABK kapal yang } \\
\text { diadhoc diatas speeboat pengawasan }\end{array}$ & Adanya perlawanan fisik/verbal & $\begin{array}{l}\text { Cedera } \\
\text { berat }\end{array}$ \\
\hline 6 & $\begin{array}{l}\text { ABK dan pengawas perikanan } \\
\text { melakukan pengamanan di atas kapal } \\
\text { perikanan yang diadhoc dan memastikan } \\
\text { sampai ke homebase }\end{array}$ & $\begin{array}{l}\text { Kapal yang diadhoc tidak diarahkan } \\
\text { ke homebase pengawasan, perlawanan } \\
\text { fisik/verbal }\end{array}$ & $\begin{array}{l}\text { Cedera } \\
\text { berat }\end{array}$ \\
\hline 7 & $\begin{array}{l}\text { ABK dan pengawas perikanan } \\
\text { menyiapkan tali tambat dan dampra } \\
\text { untuk sandar di dermaga }\end{array}$ & $\begin{array}{l}\text { Abk dan pengawas perikanan terlilit } \\
\text { tali tambat, terjatuh, terjepit }\end{array}$ & $\begin{array}{l}\text { Cedera } \\
\text { berat }\end{array}$ \\
\hline 8 & $\begin{array}{l}\text { Kapten speedboat pengawasan melalukan } \\
\text { manuver kapal di kolam pelabuhan untuk } \\
\text { masuk ke dermaga }\end{array}$ & Tabrakan kapal karena alur sempit & $\begin{array}{l}\text { Cedera } \\
\text { berat }\end{array}$ \\
\hline 9 & $\begin{array}{l}\text { Abk dan pengawas perikanan } \\
\text { menyiapkan dampra agar tidak tabrakan } \\
\text { dengan kapal lain }\end{array}$ & $\begin{array}{l}\text { Dampra jatuh, tidak terikat dengan } \\
\text { baik, kapal tabrakan }\end{array}$ & $\begin{array}{l}\text { Cedera } \\
\text { berat }\end{array}$ \\
\hline 10 & $\begin{array}{l}\text { Abk dan pengawas perikanan } \\
\text { melemparkan tali tambat dan menariknya } \\
\text { untuk sandar di dermaga }\end{array}$ & $\begin{array}{l}\text { Tali terlepas dan jatuh ke laut, kapal } \\
\text { tidak bisa sandar ke dermaga }\end{array}$ & Kelelahan \\
\hline 11 & $\begin{array}{l}\text { Penjaga dermaga mengatur kapal } \\
\text { perikanan yang di adhoc di dermaga } \\
\text { kapal pengawas }\end{array}$ & Terjepit kapal yang akan sandar & $\begin{array}{l}\text { Cedera } \\
\text { berat }\end{array}$ \\
\hline 12 & $\begin{array}{l}\text { Abk, pengawas perikanan, ppns turun } \\
\text { dari speedboat pengawasan menuju } \\
\text { dermaga }\end{array}$ & Pijakan kaki tidak stabil, terjatuh & $\begin{array}{l}\text { Cedera } \\
\text { berat }\end{array}$ \\
\hline 13 & $\begin{array}{l}\text { Abk, nakhoda kapal yang di adhoc turun } \\
\text { dari speeadboat pengawasan dan kapal } \\
\text { yang di adhoc menuju dermaga }\end{array}$ & Pijakan kaki tidak stabil, terjatuh & $\begin{array}{l}\text { Cedera } \\
\text { berat }\end{array}$ \\
\hline 14 & $\begin{array}{l}\text { Ppns menyiapkan kendaraan khusus } \\
\text { untuk membawa nakhoda dan abk kapal } \\
\text { perikanan yang di adhoc ke Pangkalan } \\
\text { PSDKP Jakarta }\end{array}$ & $\begin{array}{l}\text { Nakhoda, abk kapal yang di adhoc } \\
\text { kabur }\end{array}$ & Kelelahan \\
\hline
\end{tabular}


utama yang teridentifikasi adalah 4 aktivitas, yaitu persiapan, loading, pelayaran dan pengawasan di laut, penghentian, pemeriksaan dan penahanan kapal perikanan dan kembali ke pangkalan (homebase). Pada setiap aktivitas mempunyai konsekuensi kegagalan yang disebabkan salah satunya oleh kecerobohan/keterbatasan kemampuan manusia.

2. Pada aktivitas patroli pengawasan SDKP di laut teridentifikasi masing-masing konsekuensi kegagalan dari aktivitas yaitu kelelahan $25 \%$, luka ringan 14,29\%, cedere ringan $7,14 \%$, cedera berat $38,10 \%$, dan fatal $15.48 \%$. Secara umum, penyebab terjadinya kegagalan pada setiap aktifitas dipengaruhi oleh beberapa hal, antara lain adanya dorongan untuk menggunakan prosedur yang berbahaya, lingkungan yang buruk atau tidak mendukung dan adanya bahaya dari keterbatasan kemampuan fisik.

Adapun saran dari peneliti yaitu merekomendasikan aktivitas patroli pengawasan SDKP di laut yang dilakukan oleh pengawas perikanan di Pangkalan PSDKP Jakarta yaitu melengkapi alat perlindungan diri, antara lain berupa pelindung kepala dari sengatan matahari, alas kaki agar tidak licin, sarung tangan saat bekerja, dampra dan tali tambat yang mampu menahan beban speedboat pada saat tambat dengan kapal lain serta life jacket yang harus selalu digunakan setiap aktivitas di atas speedboat pengawasan. Selain itu diperlukan penelitian lanjutan untuk mengukur peluang risiko terjadinya kecelakaan akibat kesalahan manusia dengan pendekatan sistem keselamatan kerja pengawas perikanan pada patroli laut pengawasan SDKP di Pangkalan PSDKP Jakarta.

\section{DAFTAR PUSTAKA}

Andi, Alifen RS, Chandra A. 2005. Model Persamaan Struktural Pengaruh Budaya Keselamatan Kerja Pada Perilaku Pekerja di Proyek Konstruksi. Jurnal Teknik Sipil Untar. 12(3):127-136.

Badan Nasional Penanggulangan Bencana. 2014. Data Kecelakaan Transportasi[internet].(2014[diakses $2015 \quad$ November 13]). Tersedia pada http://geospasial.bnpb.go.id/pantauanbencana/data/datakctransportasi.php.

Davies F, Spencer R, Dooley K. 2001. Summary Guide to Safety Climate tool. Oxford (GB): HSE. 45p.

[FAO] Food Agriculture Organization. 2010. Safety At Sea For Small-Scale Fisheries In Developing Countries. Safety For Fishermen: The Way Forward (GCP/GLO/200/MUL). Field Document No.10. Rome (IT): FAO. 83 p.

Handayani SN. 2014. Sistem Keselamatan Kerja Nelayan pada Perikanan Soma Pajeko (Mini Purse Seine) di Bitung. [Tesis]. Bogor : Sekolah Pascasarjana, Institut Pertanian Bogor. 103hlm.

Handayani SN, Wisudo SH, Iskandar BH, Haluan J. 2014. Intensitas Kerja Aktivitas Nelayan Pada Pengoperasian Soma Pajeko (Mini Purse Seine) Di Bitung. Jurnal Teknologi Perikanan dan Kelautan. 5(1):1-13.

[IMO] International Maritime Organization. 2007. Formal Safety Assessment. Consolidated Text of the Guidelines for Formal Safety Assessment (FSA) for use in the IMO rules-making process (MSC/Circ.1023-MEPC/Circ.392), London (GB): Maritime Safety Committee.

KKP] Kementerian Kelautan dan Perikanan. 2013. Keputusan Direktur Jenderal Pengawasan Sumber Daya Kelautan dan Perikanan Nomor KEP 392/DJPSDKP/XII/2013 tentang Petunujuk Teknis Pengoperasian Speedboat Pengawasan Sumber Daya Kelautan dan Perikanan.

[KKP] Kementerian Kelautan dan Perikanan. 2014. Peraturan Menteri Kelautan dan Perikanan Nomor 17/PERMEN-KP/2014 tentang Pelaksanaan Tugas Pengawas Perikanan. 
Lane R, Stanton N, Harisson D. 2008. Hierarchical Task Analysis to Medication Administration Errors. Uxbridge (GB): Departemen of Design and Information System, Brunel University.

Restuputri DP, Sari RPD. 2015. Analisis Kecelakaan Kerja Dengan Menggunakan Metode Hazard and Operability Study (HAZOP). Jurnal Ilmiah Teknik Industri Universitas Muhammadiyah Malang. 4(1):24-35.

Sugiyono. 2011. Metode Penelitian Kuantitatif, Kualitatif dan R\&D. Bandung (ID): Alfabeta. hlm 85.

Suwardjo D, Haluan J, Jaya I, Poernomo SH. 2010. Kajian Tingkat Kecelakaan Fatal, Pencegahan dan Mitigasi Kecelakaan Kapal - Kapal Penangkap Ikan yang Berbasis Operasi di PPP Tegalsari, PPN Pekalongan dan PPS Cilacap. Jurnal Teknologi Perikanan dan Kelautan. 10(1):61-72.

Williams JC. 1986. A proposed Method for Assessing and Reducing Human error. In Proceedings of the 9th Advance in Reliability Technology Symposium, University of Bradford, 1986, pp. B3/R/1 $-\mathrm{B} 3 / \mathrm{R} / 13$. 